\title{
POTENTIAL IMPACTS OF WEATHER AND TRAFFIC CONDITIONS ON ROAD SURFACE PERFORMANCE IN TERMS OF FOREST OPERATIONS CONTINUITY
}

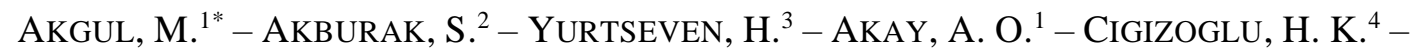 \\ DEMIR, M. ${ }^{1}-$ OZTURK, T. ${ }^{1}-$ EKSI, M. ${ }^{5}$ \\ ${ }^{I}$ Department of Forest Construction and Transportation, Faculty of Forestry, Istanbul \\ University-Cerrahpasa, 34473 Bahcekoy, Istanbul, Turkey \\ ${ }^{2}$ Department of Soil Science and Ecology, Faculty of Forestry, Istanbul University-Cerrahpasa, \\ 34473 Bahcekoy, Istanbul, Turkey \\ ${ }^{3}$ Department of Surveying and Cadastre, Faculty of Forestry, Istanbul University-Cerrahpasa, \\ 34473 Bahcekoy, Istanbul, Turkey \\ ${ }^{4}$ Department of Civil Engineering, Faculty of Civil Engineering, Istanbul Technical University \\ 34467 Maslak, Istanbul, Turkey \\ ${ }^{5}$ Department of Landscape Architecture, Faculty of Forestry, Istanbul University-Cerrahpasa \\ 34473 Bahcekoy, Istanbul, Turkey \\ *Corresponding author \\ e-mail:makgul@istanbul.edu.tr \\ (Received $6^{\text {th }}$ Nov 2018; accepted $4^{\text {th }}$ Feb 2019)
}

\begin{abstract}
The aim of this study was to evaluate the changes in forest road pavement bearing capacity (PBC) depending on meteorological conditions, traffic effects and horizontal curve parameters for a year on a monthly basis. Within this context, two different roads were investigated and measured with dynamic cone-penetrometer. The total number of the measurement points was 265 for traffic-restricted road (road no: 001-RN1) and 315 for open traffic road (road no: 005-RN2). In the study, three multiple regression models were developed to estimate PBC values on forest road. According to Model1, which was developed to estimate $\mathrm{PBC}$ values depending on vehicle traffic and on meteorological factors for alignment section of the $\mathrm{RN} 2$, the adjusted $\mathrm{R}^{2}$ was found to be 0.635 . In Model2 for the curve section of the RN2, the adjusted $\mathrm{R}^{2}$ was found to be 0.711 . Model3 for RN1 depending on meteorological factors demonstrated that the accuracy of PBC estimation had a high adjusted $\mathrm{R}^{2}$, which was 0.952 . In conclusion, $\mathrm{PBC}$ values can be estimated at high accuracy. Furthermore, traffic load has a strong effect on PBC. On the other hand, temperature has an important negative effect on the variation in $\mathrm{PBC}$ on RN1.
\end{abstract}

Keywords: forest road, meteorological data, traffic volume, bearing capacity, pavement

\section{Introduction}

Roads provide access for people to work, enjoy, or consider natural ecosystems (Demir, 2007). Forest road ecosystem includes both the paved and unpaved rights of way and adjacent structure, including other infrastructure, ditches, drainage features, and other components that provide the means for vegetation to establish and provide habitat for associated plants and animals (Lugo and Gucinski, 2000). Forest roads have several functions with respect to the management of forestry activities (Acar, 2016; Demir and Hasdemir, 2005). One of these main functions is the transport of timber from its point of felling to the mill. It accounts for a high proportion of the 
costs to the industry (Dawson, 2001). For that reason, different heavy vehicles operate on forest roads to manage forestry activities and forest operations. On the other hand, therefore, so as to fulfil these functions, pavement is an important element on forest roads (Akay et al., 2018). However, land degradation and pavement deteriorates in time depending on climate factors, traffic load, maintenance works, slope degree, canopy closure and other factors (Haas, 2001; Tighe et al., 2003; Akgul et al, 2017; Akgul and Hasdemir, 2018; Gokbulak et al., 2018; Sheikh et al., 2017; Yurtseven et al., 2019). Also, pavement deterioration occurs depending on pavement surface compaction rate. Pavement deterioration is the most important factor for traffic safety and safe drive of vehicles. Pavement performance changes depending on deterioration (Akgul et al., 2016).

Pavement deterioration can be slowed down or stopped with proper maintenance. For this reason, it is essential to evaluate the structural condition of a pavement, for example its bearing capacity (Domitrovic and Rukavina, 2013). On the other hand, Kiss et al. (2016) emphasized that in order to prevent significant road deterioration, high bearing capacity is required for the roads which are intensively used by the vehicles. The bearing capacity of a pavement system is defined as the number of wheels passages that it can support before it reaches structural distress (O'mahony et al., 2000). Direct measurement of the bearing capacity is not possible. Instead, the deflection caused by a known load can be measured, and then the bearing capacity can be calculated (Primusz et al., 2015). Most of the devices used to measure the bearing capacity of forest roads express the measurement results with regard to elastic modulus (Kaakkurivaara et al., 2015)

The bearing capacity of a pavement mainly depends on its structure (Trzcinski and Kaczmarzyk, 2006). Besides, the diversity of traffic load and extreme meteorological conditions affect pavement structure, for example its bearing capacity (Bocz, 2009). The stresses caused by traffic load affect each pavement layer differently. For example, it causes deformations and structural changes in the pavement. Climate conditions significantly affect pavement stiffness and bearing capacity (Szentpeteri, 2013). In spring, the bearing capacity of pavement decreases because of the increase in the amount of moisture on subgrade (Charlier et al., 2009; Vestin et al., 2018). The bearing capacity of pavement is easily determined by a Dynamic Cone Penetrometer (DCP). On the other hand, DCP is a simple testing device for measuring in situ compaction, density, strength or stiffnes (Wu and Sargand, 2007; Puppala, 2008).

The objective of the study was to monitor the changes in forest road pavement bearing capacity (PBC) on two different forest roads depending on meteorological conditions, traffic effects (vehicle passages, traffic load, vehicle tonnage etc.) and road sections (horizontal curve and alignment).

\section{Material and methods}

\section{Study area}

The research area is located in the northern part of Istanbul University's Education Research and Practice Forest close to Sariyer, Istanbul. The research field is at

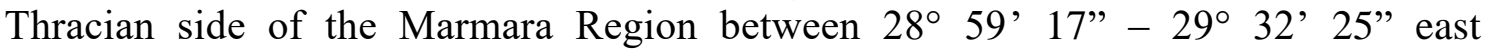
longitudes and $41^{\circ} 09^{\prime} 15^{\prime \prime}-41^{\circ} 11^{\prime} 01^{\prime \prime}$ north latitudes according to Greenwich. Within the scope of the study, two different forest roads [road no: 001 (RN1) and road no: 005 (RN2)] were selected as study areas (Fig. 1). 

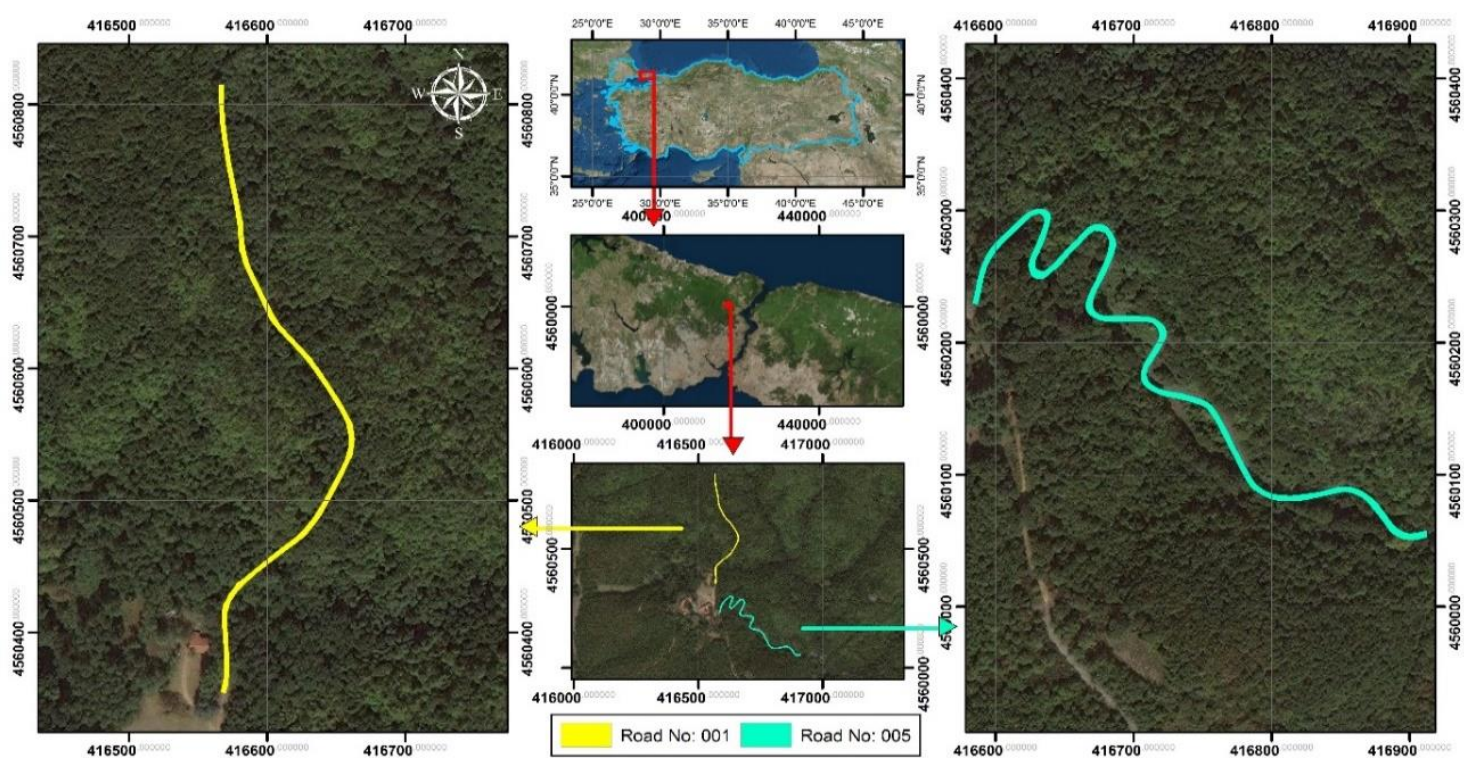

Figure 1. Location map of the study area

The RN1 and RN2 were classified as Normal Type-B forest road with 4-m platform width. The total length of the RN1 was $530 \mathrm{~m}$ while the total length of the RN2 was $684 \mathrm{~m}$. The average slope of the RN1 was $8 \%$, while the average slope of the RN2 was $12 \%$. The RN1 was composed of nine horizontal curves while RN2 was composed of eleven horizontal curves. The minimum curve radius was $9.0 \mathrm{~m}$ while maximum curve radius was $200 \mathrm{~m}$ for $\mathrm{RN} 1$, and the minimum curve radius was $6.8 \mathrm{~m}$ while maximum curve radius was $50.3 \mathrm{~m}$ for $\mathrm{RN} 2$ (Table 1).

Table 1. Geometrical specifications of roads

\begin{tabular}{|c|c|c|c|c|c|c|c|c|c|c|}
\hline & No & Type & $\begin{array}{c}\text { Length } \\
\text { (m) }\end{array}$ & $\begin{array}{c}\text { Radius } \\
\text { (m) }\end{array}$ & $\begin{array}{c}\text { Direction } \\
\text { (grad) }\end{array}$ & $\begin{array}{c}\text { Start } \\
\text { station } \\
(\mathrm{m})\end{array}$ & $\begin{array}{c}\text { End } \\
\text { station } \\
(\mathbf{m})\end{array}$ & $\begin{array}{c}\text { Delta } \\
\text { angle } \\
\text { (grad) }\end{array}$ & $\begin{array}{c}\text { Chord } \\
\text { length } \\
(\mathrm{m})\end{array}$ & $\begin{array}{c}\text { Degree of } \\
\text { curvature } \\
\text { by arc } \\
\text { (grad) }\end{array}$ \\
\hline \multirow{19}{*}{$\overline{\mathbf{Z}}$} & 1 & Alignment & 8.521 & \multirow{3}{*}{39.602} & 15.064 & $0+000.00$ & $0+008.52$ & \multirow{3}{*}{18.140} & \multirow{3}{*}{11.246} & \multirow{3}{*}{48.226} \\
\hline & 2 & Curve & 11.285 & & & $0+008.52$ & $0+019.81$ & & & \\
\hline & 3 & Alignment & 31.272 & & 396.924 & $0+019.81$ & $0+051.08$ & & & \\
\hline & 4 & Curve & 38.758 & \multirow[t]{2}{*}{42.441} & & $0+051.08$ & $0+089.84$ & \multirow[t]{2}{*}{58.136} & \multirow[t]{2}{*}{37.425} & \multirow[t]{2}{*}{44.999} \\
\hline & 5 & Alignment & 25.245 & & 55.060 & $0+089.84$ & $0+115.08$ & & & \\
\hline & 6 & Curve & 78.910 & \multirow[t]{2}{*}{200} & & $0+115.08$ & $0+193.99$ & \multirow[t]{2}{*}{25.117} & \multirow[t]{2}{*}{78.399} & \multirow[t]{2}{*}{9.549} \\
\hline & 7 & Alignment & 19.991 & & 29.9432 & $0+193.99$ & $0+213.98$ & & & \\
\hline & 8 & Curve & 24.327 & \multirow[t]{2}{*}{23.971} & & $0+213.98$ & $0+238.31$ & \multirow[t]{2}{*}{64.608} & \multirow[t]{2}{*}{23.296} & \multirow[t]{2}{*}{79.675} \\
\hline & 9 & Alignment & 36.185 & & 365.334 & $0+238.31$ & $0+274.49$ & & & \\
\hline & 10 & Curve & 35.593 & \multirow[t]{2}{*}{200} & & $0+274.49$ & $0+310.09$ & \multirow[t]{2}{*}{11.329} & \multirow[t]{2}{*}{35.546} & \multirow[t]{2}{*}{9.549} \\
\hline & 11 & Alignment & 13.724 & & 354.004 & $0+310.09$ & $0+323.81$ & & & \\
\hline & 12 & Curve & 18.178 & \multirow[t]{2}{*}{64.663} & & $0+323.81$ & $0+341.99$ & \multirow[t]{2}{*}{17.896} & \multirow[t]{2}{*}{18.118} & \multirow[t]{2}{*}{29.535} \\
\hline & 13 & Alignment & 8.440 & & 371.901 & $0+341.99$ & $0+350.43$ & & & \\
\hline & 14 & Curve & 65.77 & \multirow[t]{2}{*}{200} & & $0+350.43$ & $0+416.20$ & \multirow[t]{2}{*}{20.936} & \multirow[t]{2}{*}{65.478} & \multirow[t]{2}{*}{9.549} \\
\hline & 15 & Alignment & 0.386 & & 392.837 & $0+416.20$ & $0+416.59$ & & & \\
\hline & 16 & Curve & 0.515 & \multirow[t]{2}{*}{9.066} & & $0+416.59$ & $0+417.10$ & \multirow[t]{2}{*}{3.614} & \multirow[t]{2}{*}{0.515} & \multirow[t]{2}{*}{210.652} \\
\hline & 17 & Alignment & 56.472 & & 389.223 & $0+417.10$ & $0+473.57$ & & & \\
\hline & 18 & Curve & 28.090 & \multirow[t]{2}{*}{200.000} & & $0+473.57$ & $0+530.00$ & 8.941 & 28.067 & 9.549 \\
\hline & 19 & Alignment & 15.711 & & 398.164 & $0+501.66$ & $0+517.38$ & & & \\
\hline
\end{tabular}




\begin{tabular}{|c|c|c|c|c|c|c|c|c|c|c|}
\hline \multirow{23}{*}{$\underset{\check{Z}}{\check{Z}}$} & 1 & Alignment & 21.816 & & 13.081 & $0+000.00$ & $0+021.82$ & & & \\
\hline & 2 & Curve & 28.317 & 50.353 & & $0+021.82$ & $0+050.13$ & 35.801 & 27.945 & 37.929 \\
\hline & 3 & Alignment & 30.400 & & 48.882 & $0+050.13$ & $0+080.53$ & & & \\
\hline & 4 & Curve & 22.514 & 8.161 & & $0+080.53$ & $0+103.05$ & 175.619 & 16.024 & 234.015 \\
\hline & 5 & Alignment & 30.161 & & 224.502 & $0+103.05$ & $0+133.21$ & & & \\
\hline & 6 & Curve & 18.797 & 6.830 & & $0+133.21$ & $0+152.00$ & 175.195 & 13.402 & 279.609 \\
\hline & 7 & Alignment & 40.883 & & 49.306 & $0+152.00$ & $0+192.89$ & & & \\
\hline & 8 & Curve & 32.824 & 11.772 & & $0+192.89$ & $0+225.71$ & 177.500 & 23.178 & 162.231 \\
\hline & 9 & Alignment & 38.428 & & 226.807 & $0+225.71$ & $0+264.14$ & & & \\
\hline & 10 & Curve & 22.304 & 11.294 & & $0+264.14$ & $0+286.44$ & 125.716 & 18.852 & 169.096 \\
\hline & 11 & Alignment & 30.312 & & 101.090 & $0+286.44$ & $0+316.75$ & & & \\
\hline & 12 & Curve & 23.562 & 11.457 & & $0+316.75$ & $0+340.32$ & 130.919 & 19.624 & 166.691 \\
\hline & 13 & Alignment & 22.422 & & 232.010 & $0+340.32$ & $0+362.74$ & & & \\
\hline & 14 & Curve & 23.553 & 12.642 & & $0+362.74$ & $0+386.29$ & 118.612 & 20.292 & 151.075 \\
\hline & 15 & Alignment & 26.817 & & 113.398 & $0+386.29$ & $0+413.11$ & & & \\
\hline & 16 & Curve & 21.074 & 23.375 & & $0+413.11$ & $0+434.18$ & 57.395 & 20.368 & 81.704 \\
\hline & 17 & Alignment & 49.803 & & 170.793 & $0+434.18$ & $0+483.99$ & & & \\
\hline & 18 & Curve & 44.610 & 33.759 & & $0+483.99$ & $0+528.60$ & 84.123 & 41.434 & 56.572 \\
\hline & 19 & Alignment & 28.883 & & 86.670 & $0+528.60$ & $0+557.48$ & & & \\
\hline & 20 & Curve & 29.577 & 25.601 & & $0+557.48$ & $0+587.06$ & 73.550 & 27.96 & 74.601 \\
\hline & 21 & Alignment & 20.584 & & 160.221 & $0+587.06$ & $0+607.64$ & & & \\
\hline & 22 & Curve & 23.604 & 19.822 & & $0+607.64$ & $0+631.24$ & 75.800 & 22.234 & 96.350 \\
\hline & 23 & Alignment & 53.464 & & 84.412 & $0+631.24$ & $0+684.71$ & & & \\
\hline
\end{tabular}

\section{Meteorological data (weather conditions)}

Weather data was continuously recorded at the adjacent weather station at the Green Roof Research Site located in Istanbul University Faculty of Forestry. Weather data was measured by an automated weather station (DeltaOhm HD2003). Precipitation measurements (hourly basis) were performed using a rain gauge (DeltaOhm HD2003 tipping bucket, measurement accuracy $\pm 1 \%$ ). Also, weather data recorded during study period were compared to long term meteorological data between 1929 and 2017 for the research field which were listed in Table 2 (General Directory of Meteorology-GDM, 2018).

Table 2. Long term meteorological data from Istanbul (1929-2017) (GDM, 2018)

\begin{tabular}{c|c|c|c|c|c|c|c|c|c|c|c|c|c}
\hline & \multicolumn{10}{c|}{ Months } & \multirow{2}{*}{ Annual } \\
\cline { 2 - 12 } & I & II & III & IV & V & VI & VII & VIII & IX & X & XI & XII & \\
\hline Mean temperature $\left({ }^{\circ} \mathrm{C}\right)$ & 6.0 & 6.1 & 7.7 & 12.0 & 16.7 & 21.4 & 23.8 & 23.8 & 20.1 & 15.7 & 11.7 & 8.3 & 14.4 \\
Maximum temperature $\left({ }^{\circ} \mathrm{C}\right)$ & 8.4 & 9.0 & 10.9 & 15.4 & 20.0 & 24.6 & 26.6 & 26.8 & 23.7 & 19.1 & 14.8 & 10.8 & 17.5 \\
Minimum temperature $\left({ }^{\circ} \mathrm{C}\right)$ & 3.1 & 3.1 & 4.2 & 7.6 & 12.1 & 16.5 & 19.4 & 20.1 & 16.8 & 12.9 & 8.9 & 5.5 & 10.8 \\
Precipitation $(\mathrm{mm})$ & 106.0 & 77.7 & 71.4 & 45.9 & 34.4 & 36.0 & 33.3 & 39.9 & 61.7 & 88.0 & 100.9 & 122.2 & 817.4 \\
\hline
\end{tabular}

\section{Data collection for traffic characterization}

Within the scope of the study, camera traps were installed to observe traffic characterization of the RN2. The RN1 was restricted to vehicle passages for one year. The camera traps (Bushnell Trophy Cam, 8MP) were positioned on tree trunks at both the start and end section of the RN2. The camera traps were programmed to take photo at $1 \mathrm{sec}$ interval. The pictures taken by the camera traps were controlled on a monthly basis from September 2015 to September 2016. Vehicle tonnages were calculated in 
four groups (automobile, crossover \& SUV, minibus, pickup) according to vehicle types.

\section{Measurement of PBC and data collection}

In this study, in order to measure PBC, 53 measurement lines (30 lines in curve section; 23 lines in alignment section) at 10-m intervals were determined along the RN1 while 63 measurement lines (29 lines in curve section; 34 lines in alignment section) at 10-m intervals were determined along the RN2 (Fig. 2).

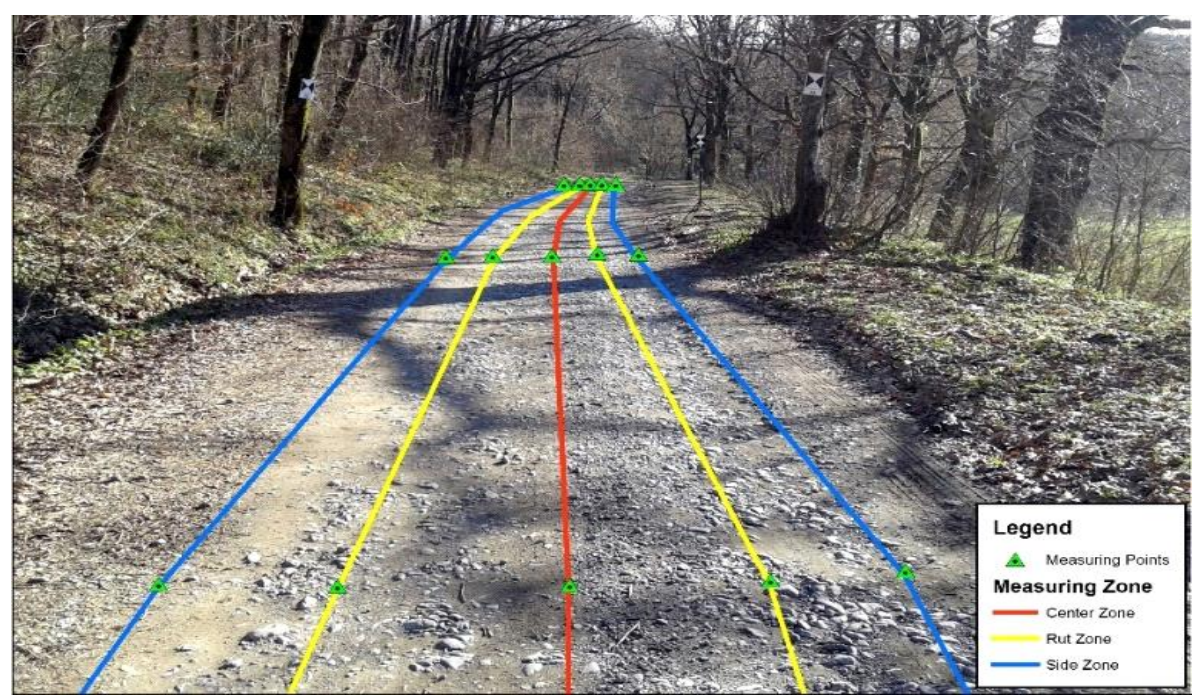

Figure 2. Penetrometer measuring points

Five penetrometer measurement points were set on each measurement line with a right angle to the road platform. In total, 265 measurement points (150 points in curve section; 115 point in alignment section) were established for the RN1 and 315 measurement points (145 points in curve section; 170 points in alignment section) were established for the RN2.

The measurement points were fixed with nails $(20 \mathrm{~cm}$ length). The coordinates of each measurement point were measured by Pentax W800 total station in UTM ED1950 coordinate system (Fig. 3).
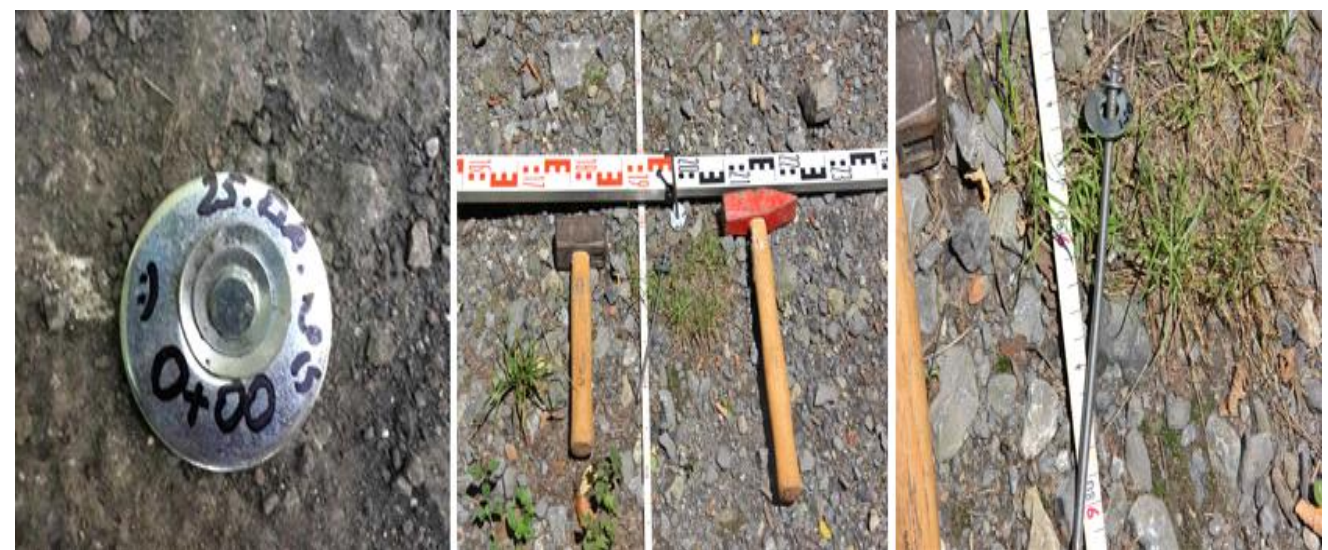

Figure 3. Establishment of measurement points 
PBC was measured using a penetrologger (Eijkelkamp Agrisearch Equipment, the Netherlands). Thirty-degree cones were used with a cone basal surface area of $1 \mathrm{~cm}^{2}$ (nominal diameter $11.28 \mathrm{~mm}$ ) (Fig. 4). Data collection was conducted from October 2015 to September 2016 on a monthly basis.

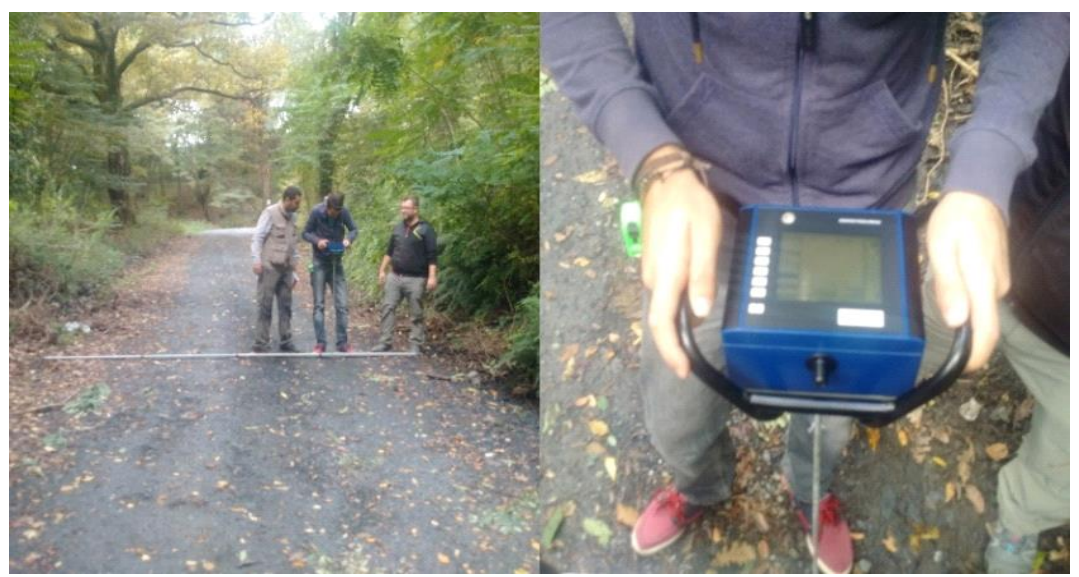

Figure 4. Data collection

\section{Statistical analysis}

All statistical analyses were performed using SPSS 23.0 statistical package. In order to estimate the effects of road geometrical properties on PBC, two different multiple regression models were developed for both road alignments and curves on the RN2. Moreover, multiple linear regression model was developed for the in RN1 to estimate the effects of meteorological parameters on PBC. To evaluate the accuracy of the mathematical model by regression analysis, $80 \%$ of the total number of the variables ( $N=1668$ for alignment section of RN2; $N=1371$ for curve section of RN2; $N=2540$ for RN1) were randomly selected and used as calibration data, while $20 \%$ of them ( $N=432$ for alignment section of RN2; $N=369$ for curve section of RN2; $N=640$ RN1) were also used as testing data. Furthermore, paired sample $t$-Test and correlation analysis were used to calculate the significance level of the models.

\section{Results and discussion}

\section{Results of meteorological data}

According to the meteorological data, the minimum average temperature was measured in February as $6.50{ }^{\circ} \mathrm{C}$ while the maximum was measured in August as $24.52{ }^{\circ} \mathrm{C}$. The maximum total precipitation was measured in February as $130.1 \mathrm{~mm}$ while the minimum was measured in September as $9.6 \mathrm{~mm}$ (Table 3).

\section{Results of traffic characteristics}

According to the camera traps, 4598 vehicle passages were observed from September 2015 to September 2016 (Table 4; Fig. 5). The minimum total vehicle passages were in January as with 80 passages while the maximum total vehicle passages on monthly basis was in September 2016, which reached 1604 passages. Moreover, the average speed of vehicles was calculated as $30 \mathrm{~km} / \mathrm{h}$ for this road. 
Table 3. Meteorological data

\begin{tabular}{c|c|c|c|c|c|c}
\hline Year & Months & $\begin{array}{c}\text { Mean } \\
\text { temperature } \\
\left({ }^{\circ} \mathbf{C}\right)\end{array}$ & $\begin{array}{c}\text { Total } \\
\text { precipitation } \\
(\mathbf{m m})\end{array}$ & $\begin{array}{c}\text { Rainfall } \\
\text { duration }(\mathbf{h})\end{array}$ & $\begin{array}{c}\text { Precipitation } \\
\text { intensity } \\
(\mathbf{m m} / \mathbf{h})\end{array}$ & $\begin{array}{c}\text { Mean pressure } \\
(\mathbf{M b a r})\end{array}$ \\
\hline \multirow{3}{*}{2015} & November & 19.19 & 143.4 & 359 & 0.40 & 987.46 \\
& October & 13.75 & 75.5 & 155 & 0.48 & 992.48 \\
& December & 10.52 & 56 & 223 & 0.25 & 991.78 \\
\hline \multirow{6}{*}{2016} & January & 6.66 & 87.3 & 365 & 0.240 & 991.48 \\
& February & 6.50 & 130.1 & 399 & 0.33 & 990.25 \\
& March & 10.70 & 63.4 & 177 & 0.36 & 985.77 \\
& April & 11.80 & 35.6 & 125 & 0.28 & 985.20 \\
& May & 15.36 & 40.6 & 154 & 0.26 & 984.20 \\
& June & 18.89 & 50.8 & 109 & 0.46 & 983.75 \\
& July & 23.72 & 45.1 & 73 & 0.62 & 985.03 \\
& August & 24.52 & 34.3 & 42 & 0.82 & 984.47 \\
& September & 23.47 & 9.6 & 36 & 0.27 & 986.18 \\
\hline
\end{tabular}

Table 4. Traffic characteristic of RN2

\begin{tabular}{|c|c|c|c|c|c|c|c|c|c|c|c|}
\hline \multirow{3}{*}{ Month } & \multirow{3}{*}{ Year } & \multirow{2}{*}{\multicolumn{2}{|c|}{$\begin{array}{c}\text { Automobile } \\
(1250 \mathrm{~kg}) \\
\end{array}$}} & \multirow{2}{*}{\multicolumn{2}{|c|}{$\begin{array}{c}\text { SUV-Crossover } \\
(2000 \mathrm{~kg})\end{array}$}} & \multirow{2}{*}{\multicolumn{2}{|c|}{$\begin{array}{l}\text { Minibus } \\
(2000 \mathrm{~kg}) \\
\end{array}$}} & \multirow{2}{*}{\multicolumn{2}{|c|}{$\begin{array}{c}\text { Pickup } \\
(3300 \mathrm{~kg}+)\end{array}$}} & \multirow{3}{*}{$\begin{array}{c}\text { Total } \\
\text { passes }\end{array}$} & \multirow{3}{*}{$\begin{array}{c}\text { Total } \\
\text { Tonnage } \\
\text { (ton) }\end{array}$} \\
\hline & & & & & & & & & & & \\
\hline & & Passes & Tonnage & Passes & Tonnage & Passes & Tonnage & Passes & Tonnage & & \\
\hline September-October & \multirow{4}{*}{$\frac{n}{8}$} & 98 & 122500 & 28 & 56000 & 42 & 84000 & 46 & 151800 & 214 & 414300 \\
\hline October-November & & 106 & 132500 & 20 & 40000 & 50 & 100000 & 22 & 72600 & 198 & 345100 \\
\hline November-December & & 172 & 215000 & 88 & 176000 & 70 & 140000 & 78 & 257400 & 408 & 788400 \\
\hline December-January & & 26 & 32500 & 6 & 12000 & 20 & 40000 & 28 & 92400 & 80 & 176900 \\
\hline January-February & \multirow{9}{*}{$\stackrel{0}{\stackrel{0}{\circ}}$} & 90 & 112500 & 52 & 104000 & 108 & 216000 & 70 & 231000 & 320 & 663500 \\
\hline February-March & & 190 & 237500 & 46 & 92000 & 88 & 176000 & 54 & 178200 & 378 & 683700 \\
\hline March-April & & 204 & 255000 & 60 & 120000 & 56 & 112000 & 58 & 191400 & 378 & 678400 \\
\hline April-May & & 110 & 137500 & 62 & 124000 & 94 & 188000 & 66 & 217800 & 332 & 667300 \\
\hline May-June & & 144 & 180000 & 58 & 116000 & 100 & 200000 & 54 & 178200 & 356 & 674200 \\
\hline June-July & & 204 & 255000 & 16 & 32000 & 12 & 24000 & 16 & 52800 & 248 & 363800 \\
\hline July-August & & 140 & 175000 & 48 & 96000 & 8 & 16000 & 4 & 13200 & 200 & 300200 \\
\hline August-September & & 172 & 215000 & 48 & 96000 & 8 & 16000 & 32 & 105600 & 260 & 432600 \\
\hline September-November & & 852 & 1065000 & 116 & 232000 & 408 & 816000 & 228 & 752400 & 1604 & 2865400 \\
\hline Mean & & 193 & 241154 & 50 & 99692 & 82 & 163692 & 58 & 191908 & 383 & 696446 \\
\hline
\end{tabular}

\section{Results of PBC on monthly basis}

PBC values measured monthly were calculated as mean values and are listed in Table 5. It was divided into two main columns as curve section and alignment section for monitoring PBC differences between the RN1 and RN2. The table demonstrates that the measured PBC values of the RN1 were lower than those of the RN2. Furthermore, the measurement results showed that $\mathrm{PBC}$ values of the curve sections were relatively lower than those of the alignment sections on the RN2. A comparison of PBC values between the curve section of the RN1 and that of the RN2 revealed that PBC values of the RN2 was almost two times higher than those of the RN1 (Fig. 6). 

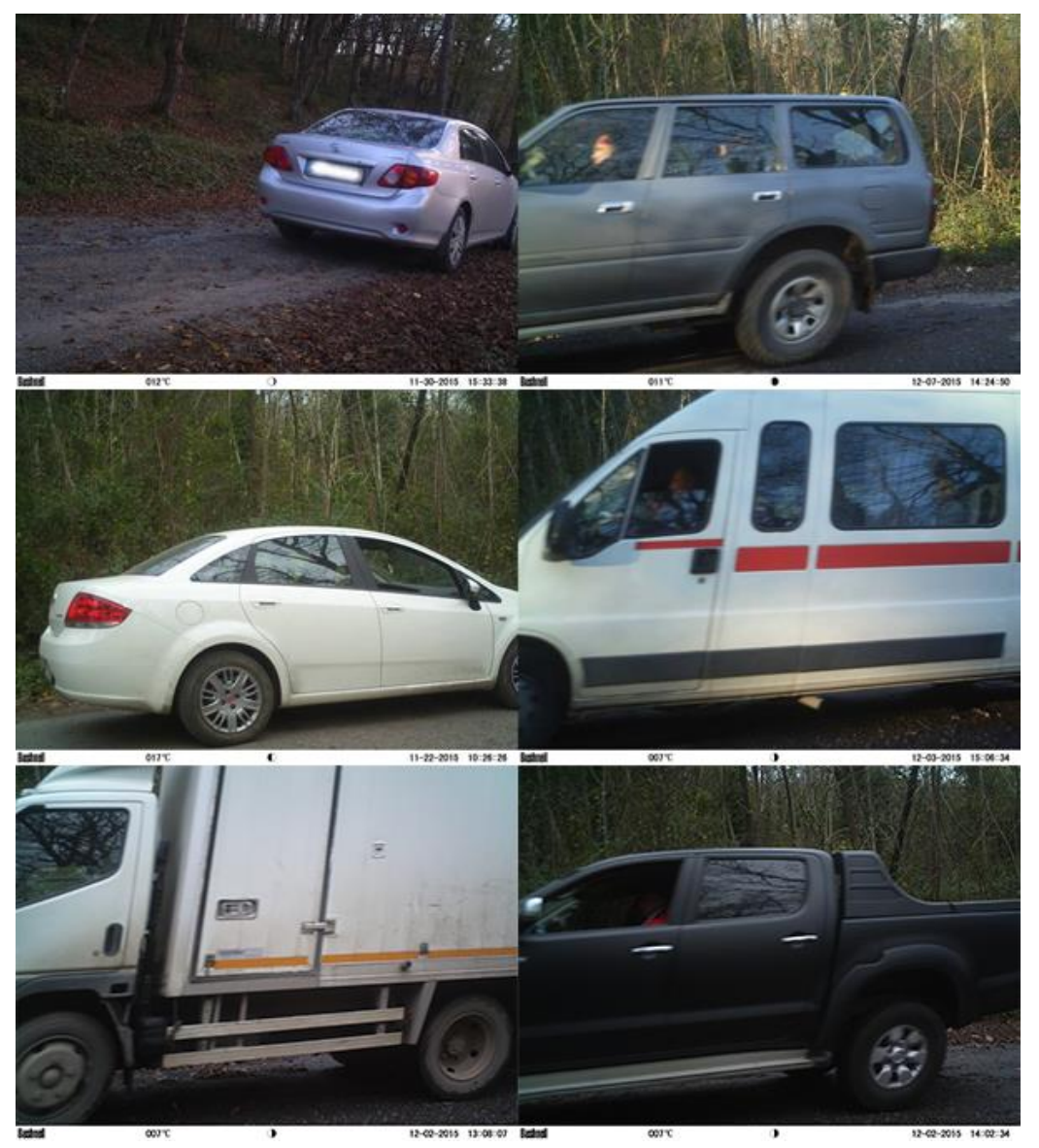

Figure 5. Sample pictures which were taken from camera traps

Table 5. Mean PBC values on curves and alignment for RN1 and RN2

\begin{tabular}{|c|c|c|c|c|c|c|c|c|c|c|c|c|}
\hline \multirow{3}{*}{ Month } & \multicolumn{6}{|c|}{ RN2 } & \multicolumn{6}{|c|}{ RN1 } \\
\hline & \multicolumn{3}{|c|}{ Curve section } & \multicolumn{3}{|c|}{ Alignment section } & \multicolumn{3}{|c|}{ Curve section } & \multicolumn{3}{|c|}{ Alignment section } \\
\hline & $\begin{array}{c}\text { Side } \\
\text { Zone } \\
(\mathrm{MPa})\end{array}$ & $\begin{array}{l}\text { Center } \\
\text { Zone } \\
\text { (MPa) }\end{array}$ & $\begin{array}{c}\text { Rut } \\
\text { Zone } \\
\text { (MPa) }\end{array}$ & $\begin{array}{c}\text { Side } \\
\text { Zone } \\
(\mathrm{MPa})\end{array}$ & $\begin{array}{l}\text { Center } \\
\text { Zone } \\
\text { (MPa) }\end{array}$ & $\begin{array}{c}\text { Rut } \\
\text { Zone } \\
\text { (MPa) }\end{array}$ & $\begin{array}{l}\text { Side } \\
\text { Zone } \\
\text { (MPa) }\end{array}$ & $\begin{array}{l}\text { Center } \\
\text { Zone } \\
\text { (MPa) }\end{array}$ & $\begin{array}{c}\text { Rut } \\
\text { Zone } \\
\text { (MPa) }\end{array}$ & $\begin{array}{c}\text { Side } \\
\text { Zone } \\
\text { (MPa) }\end{array}$ & $\begin{array}{l}\text { Center } \\
\text { Zone } \\
\text { (MPa) }\end{array}$ & $\begin{array}{c}\text { Rut } \\
\text { Zone } \\
\text { (MPa) }\end{array}$ \\
\hline October 2015 & 1.985 & 2.000 & 1.995 & 2.036 & 2.037 & 2.045 & 0.582 & 0.594 & 0.589 & 0.570 & 0.563 & 0.569 \\
\hline November 2015 & 2.207 & 2.234 & 2.233 & 2.204 & 2.202 & 2.213 & 0.976 & 0.991 & 0.984 & 0.973 & 0.985 & 0.988 \\
\hline December 2015 & 2.080 & 2.094 & 2.097 & 2.321 & 2.335 & 2.340 & 0.860 & 0.842 & 0.867 & 0.872 & 0.894 & 0.887 \\
\hline January 2016 & 1.922 & 1.950 & 1.949 & 2.129 & 2.134 & 2.145 & 0.681 & 0.691 & 0.688 & 0.591 & 0.600 & 0.600 \\
\hline February 2016 & 1.894 & 1.919 & 1.919 & 2.179 & 2.190 & 2.197 & 0.871 & 0.852 & 0.864 & 0.722 & 0.730 & 0.722 \\
\hline March 2016 & 1.811 & 1.823 & 1.831 & 2.157 & 2.164 & 2.172 & 1.049 & 1.055 & 1.048 & 0.987 & 1.001 & 0.988 \\
\hline April 2016 & 1.632 & 1.650 & 1.653 & 1.886 & 1.905 & 1.899 & 0.785 & 0.779 & 0.791 & 0.557 & 0.570 & 0.562 \\
\hline May 2016 & 1.640 & 1.667 & 1.667 & 1.873 & 1.883 & 1.887 & 0.686 & 0.694 & 0.688 & 0.688 & 0.670 & 0.695 \\
\hline June 2016 & 1.915 & 1.943 & 1.939 & 2.030 & 2.038 & 2.045 & 0.664 & 0.664 & 0.671 & 0.868 & 0.875 & 0.876 \\
\hline July 2016 & 1.892 & 1.921 & 1.920 & 1.969 & 1.980 & 1.985 & 0.740 & 0.745 & 0.740 & 0.663 & 0.678 & 0.672 \\
\hline August 2016 & 1.889 & 1.918 & 1.917 & 1.940 & 1.945 & 1.959 & 0.738 & 0.729 & 0.735 & 0.634 & 0.644 & 0.639 \\
\hline $\begin{array}{c}\text { September } \\
2016\end{array}$ & 1.970 & 2.000 & 1.999 & 2.073 & 2.076 & 2.089 & 0.588 & 0.582 & 0.588 & 0.494 & 0.500 & 0.492 \\
\hline Mean & 1.903 & 1.927 & 1.927 & 2.066 & 2.074 & 2.081 & 0.768 & 0.768 & 0.771 & 0.718 & 0.726 & 0.724 \\
\hline
\end{tabular}




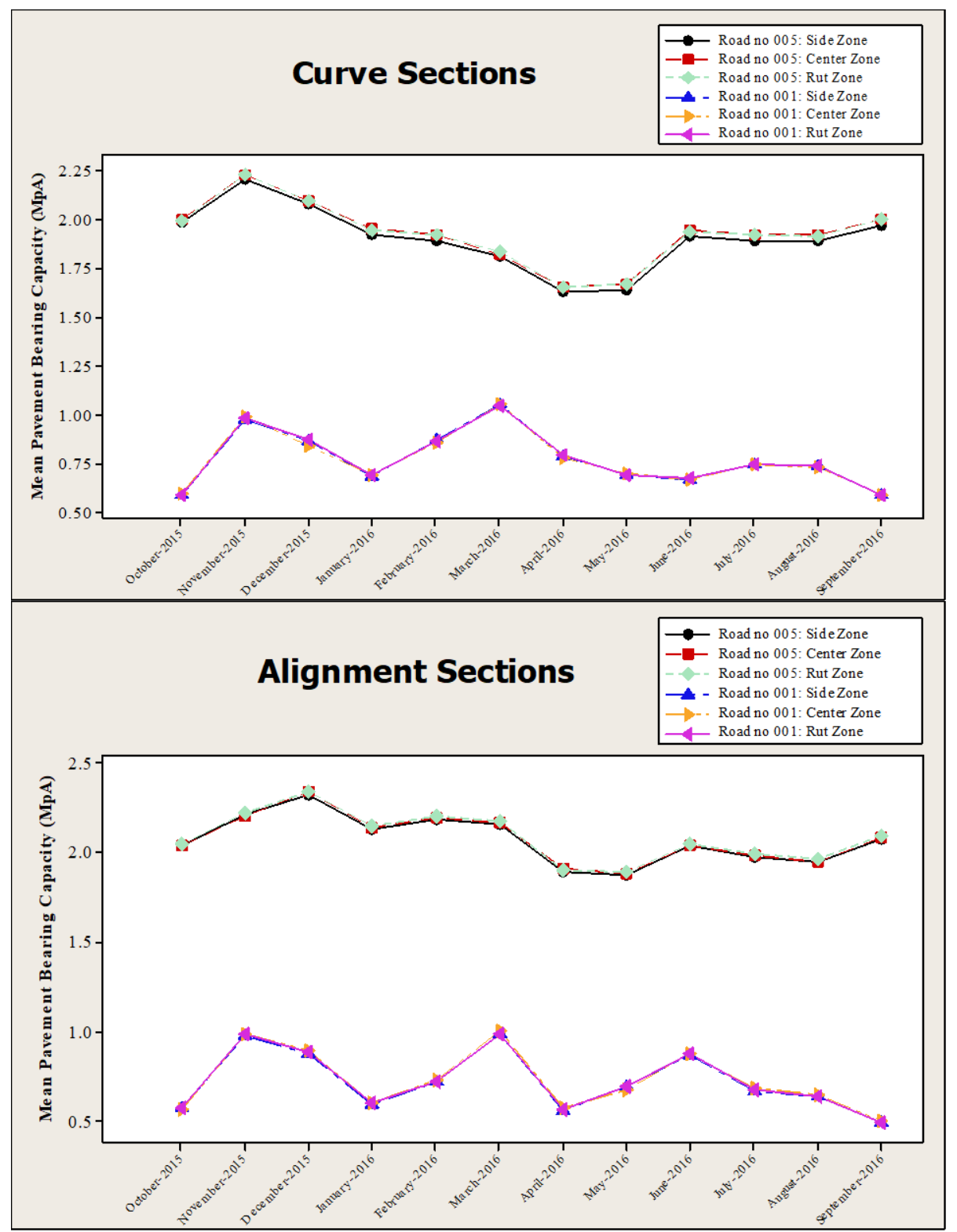

Figure 6. Mean bearing capacity on curve sections and alignment sections of RN1 and RN2

Besides, PBC values of the alignment section on the RN2 were found as three times higher than those on the RN1 (Fig. 7). PBC values were also observed to be lower in spring than in other seasons.

\section{Results of statistical model}

The descriptive statistics of the calibration data used in multiple regression model for the curve section $(N=1371)$ of the RN2 are listed in Table 6 , while they are presented in Table 7 for the alignment section $(N=1668)$ of the RN2. The descriptive statistics of the calibration data $(N=2540)$ for the RN1 are listed in Table 8 .

In order to estimate the effects of road geometrical properties on PBC, two different multiple regression models were developed for both road alignments and curves on the RN2. Moreover, multiple linear regression model was developed to estimate the effects 
of meteorological parameters on $\mathrm{PBC}$ on the RN1. In all regression models, $\mathrm{PBC}$ was considered as the dependent variable. In the regression model for the alignment section of the RN2; road zone (Z), total precipitation (Tp), tonnage (Tn), passages (Ps) were considered as independent variables, in the regression model for the curve section of the $\mathrm{RN} 2$; road zone $(\mathrm{Z})$, curve radius $(\mathrm{CuR})$, total precipitation $(\mathrm{Tp})$, precipitation intensity $(\mathrm{Pi})$, passages $(\mathrm{Ps})$, tonnage $(\mathrm{Tn})$, curve length $(\mathrm{CuL})$, while in regression model for RN1 road zone $(\mathrm{Z})$, total precipitation $(\mathrm{Tp})$, temperature $(\mathrm{Tm})$, pressure (Prs) were considered as independent variables.

At the stage of testing the statistical relationship between the variables for the curve section of the RN2, the results of Pearson's correlation coefficients and their significance levels $(\mathrm{p}<0.01)$ and correlation analysis are shown in Table 9. It was found that there was a strong positive relationship between $P B C$ and $\ln (Z),(Z)$.

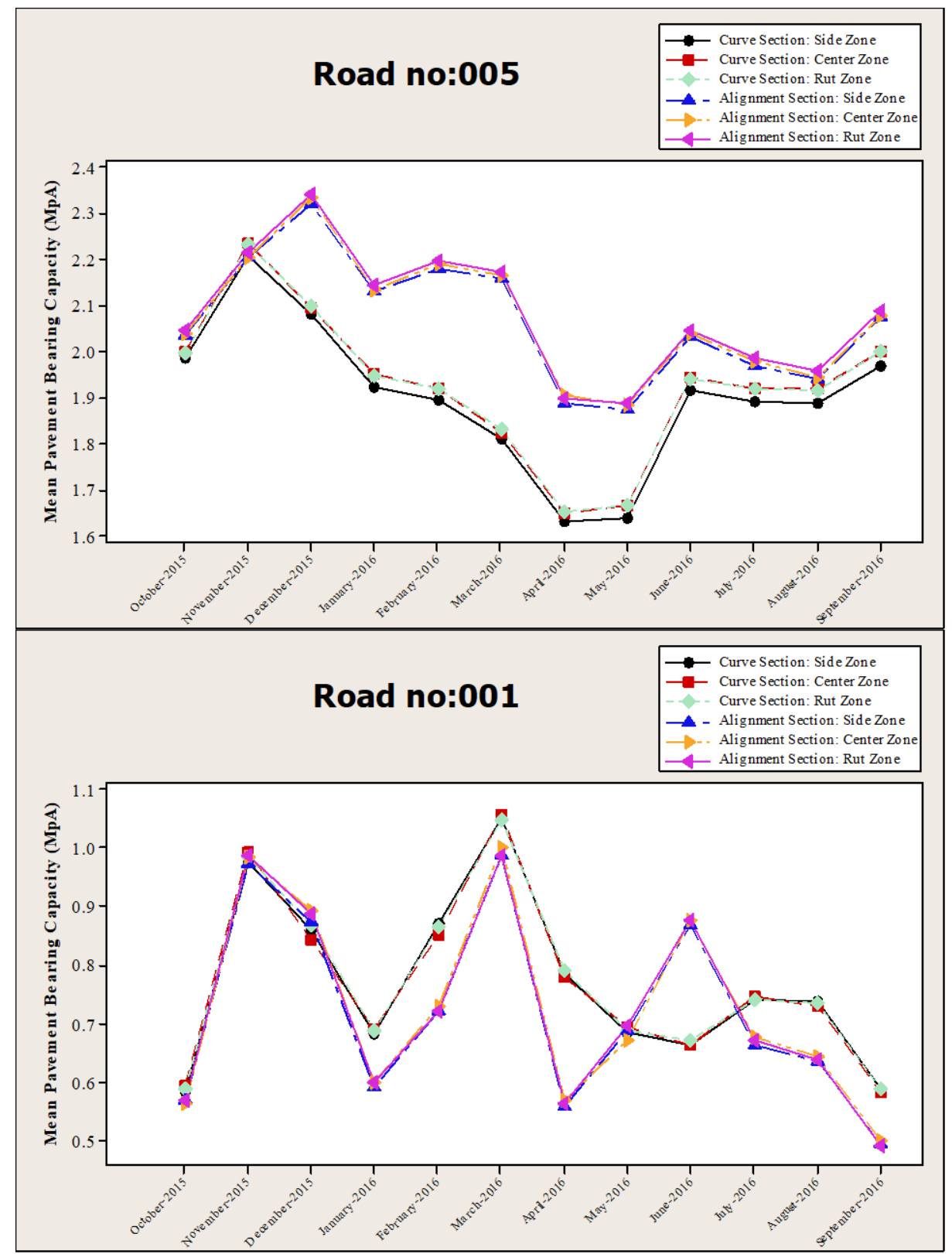

Figure 7. Mean bearing capacity on RN1 and RN2 
Table 6. Descriptive statistics for curve section of RN2

\begin{tabular}{c|c|c|c|c|c|c|c}
\hline \multirow{2}{*}{$\mathbf{R N 2}$} & $\boldsymbol{N}$ & Minimum & Maximum & \multicolumn{2}{|c|}{ Mean } & Std. deviation & Variance \\
\cline { 2 - 8 } Curve section & Statistic & Statistic & Statistic & Statistic & Std. Error & Statistic & Statistic \\
\hline In(Z) (road zone) & 1371 & 0.693 & 1.386 & 0.994 & 0.006 & 0.267 & 0.071 \\
$\mathbf{Z}$ (road zone) & 1371 & 2.000 & 4.000 & 2.800 & 0.018 & 0.749 & 0.560 \\
$\mathbf{C u R ( m )}$ & 1371 & 6.830 & 50.353 & 21.270 & 0.312 & 13.003 & 169.078 \\
$\mathbf{T p}(\mathbf{m m})$ & 1371 & 9.600 & 143.400 & 64.308 & 0.906 & 37.803 & 1429.067 \\
$\mathbf{P i}(\mathbf{m m} / \mathbf{h})$ & 1371 & 0.239 & 0.817 & 0.398 & 0.004 & 0.168 & 0.028 \\
$\mathbf{P s}(\mathbf{p a s s e s})$ & 1371 & 80.000 & 1604.000 & 383.170 & 9.079 & 378.728 & 143434.739 \\
$\mathbf{T n}(\mathbf{k g})$ & 1371 & 300.200 & 2865.400 & 784.392 & 16.003 & 667.537 & 445605.726 \\
$\mathbf{C u L}(\mathbf{m})$ & 1371 & 18.797 & 44.610 & 27.882 & 0.185 & 1.220 & 1.488 \\
$\mathbf{P B C}(\mathbf{M P a})$ & 1371 & 0.010 & 3.900 & 1.918 & 0.029 & 7.721 & 59.612 \\
\hline
\end{tabular}

Table 7. Descriptive statistics for alignment section RN2

\begin{tabular}{c|c|c|c|c|c|c|c}
\hline \multirow{2}{*}{$\begin{array}{r}\text { RN2 } \\
\text { Alignment section }\end{array}$} & $\boldsymbol{N}$ & Minimum & Maximum & \multicolumn{2}{|c|}{ Mean } & Std. deviation & Variance \\
\cline { 2 - 8 } & Statistic & Statistic & Statistic & Statistic & Std. Error & Statistic & Statistic \\
\hline $\ln (\mathbf{Z})$ (road zone) & 1668 & 0.693 & 1.386 & 0.992 & 0.007 & 0.268 & 0.072 \\
$\mathbf{Z}$ (road zone) & 1668 & 2.000 & 4.000 & 2.800 & 0.018 & 0.752 & 0.566 \\
Tp (mm) & 1668 & 9.600 & 143.400 & 64.507 & 0.928 & 37.910 & 1437.178 \\
Tn (kg) & 1668 & 300.200 & 2865.400 & 781.825 & 16.300 & 665.697 & 443152.172 \\
Ps (passes) & 1668 & 80.000 & 1604.000 & 382.140 & 9.246 & 377.619 & 142596.100 \\
PBC (MPa) & 1668 & 0.020 & 3.996 & 2.080 & 0.030 & 1.244 & 1.547 \\
\hline
\end{tabular}

Table 8. Descriptive statistics for RN1

\begin{tabular}{c|c|c|c|c|c|c|c}
\hline \multirow{2}{*}{$\begin{array}{c}\text { RN1 } \\
\text { All road sections }\end{array}$} & $\boldsymbol{N}$ & Minimum & Maximum & \multicolumn{2}{|c|}{ Mean } & Std. deviation & Variance \\
\cline { 2 - 7 } & Statistic & Statistic & Statistic & Statistic & Std. Error & Statistic & Statistic \\
\hline $\ln (\mathbf{Z})(\mathbf{r o a d}$ zone) & 2540 & 0.693 & 1.386 & 0.995 & 0.005 & 0.268 & 0.072 \\
$\ln (\mathbf{T p})(\mathbf{m m})$ & 2540 & 2.262 & 4.966 & 3.968 & 0.014 & 0.682 & 0.466 \\
$\ln (\mathbf{T m})\left(\mathbf{(}^{\circ} \mathbf{C}\right)$ & 2540 & -1.431 & 3.200 & 1.064 & 0.037 & 1.852 & 3.409 \\
$\ln (\mathbf{P r s})(\mathbf{M b a r})$ & 2540 & 4.238 & 6.900 & 5.785 & 0.025 & 1.266 & 1.602 \\
$\ln (\mathbf{P B C})(\mathbf{M P a})$ & 2540 & -4.605 & 6.900 & 2.513 & 0.078 & 3.945 & 15.564 \\
\hline
\end{tabular}

Table 9. Correlations between variables for curve section of RN2

\begin{tabular}{c|c|c|c|c|c|c|c|c|c}
\hline & $\boldsymbol{l n}(\mathbf{Z})$ & $\boldsymbol{Z}$ & $\boldsymbol{C u R}$ & $\boldsymbol{T p}$ & $\boldsymbol{P i}$ & $\boldsymbol{P s}$ & $\boldsymbol{T n}$ & $\boldsymbol{C u L}$ & $\boldsymbol{P B C}$ \\
\hline $\boldsymbol{I n}(\mathbf{Z})$ & 1 & & & & & & & & \\
$\mathbf{Z}$ & 0.994 & 1 & & & & & & & \\
$\mathbf{C u R}$ & 0.009 & 0.010 & 1 & & & & & & \\
$\mathbf{T p}$ & -0.006 & -0.007 & -0.001 & 1 & & & & & \\
$\mathbf{P i}$ & -0.005 & -0.006 & -0.005 & -0.143 & 1 & & & & \\
$\mathbf{P s}$ & 0.014 & 0.015 & 0.018 & -0.479 & -0.289 & 1 & & & \\
$\mathbf{T n}$ & 0.015 & 0.016 & 0.013 & -0.370 & -0.329 & 0.919 & 1 & & \\
$\mathbf{C u L}$ & 0.004 & 0.006 & 0.495 & 0.017 & -0.002 & 0.004 & -0.005 & 1 & \\
$\mathbf{P B C}$ & $\mathbf{0 . 7 5 8 *}$ & $\mathbf{0 . 7 1 8 *}$ & 0.024 & 0.031 & 0.029 & 0.007 & 0.035 & -0.090 & 1 \\
\hline
\end{tabular}

*Correlation is significant at the 0.01 level 
Also, according to Pearson's correlation coefficients and their significance levels $(\mathrm{p}<0.01)$, a strong positive correlation was found between $P B C$ and $\ln (Z)$, ( $Z$ ) (Table 10).

Table 10. Correlations between variables for alignment section of RN2

\begin{tabular}{c|c|c|c|c|c|c}
\hline & $\boldsymbol{l n}(\boldsymbol{Z})$ & $\boldsymbol{Z}$ & $\boldsymbol{T p}$ & $\boldsymbol{T n}$ & $\boldsymbol{P} \boldsymbol{P}$ & $\boldsymbol{P B C}$ \\
\hline $\ln (\mathbf{Z})$ & 1 & & & & & \\
$\mathbf{Z}$ & 0.995 & 1 & & & & \\
$\mathbf{T p}$ & -0.005 & -0.005 & 1 & & & \\
$\mathbf{T n}$ & 0.010 & 0.011 & -0.367 & 1 & & \\
Ps & 0.013 & 0.013 & -0.477 & 0.917 & 1 & \\
$\mathbf{P B C}$ & $\mathbf{0 . 7 1 3 *}^{*}$ & $\mathbf{0 . 6 7 3}$ & 0.036 & 0.042 & 0.019 & 1 \\
\hline
\end{tabular}

*Correlation is significant at the 0.01 level

Considering the correlation analysis results evaluated for the RN1, their significance levels ( $\mathrm{p}<0.01$ ), there was a weak correlation between PBC and $\mathrm{Z}$ unlike the RN2 (Table 11). However, a strong negative correlation was found between PBC and Tm, Prs.

Table 11. Correlations between variables for RNI

\begin{tabular}{c|c|c|c|c|c}
\hline & $\ln (\boldsymbol{Z})$ & $\ln (\boldsymbol{T} p)$ & $\ln (\boldsymbol{T m})$ & $\ln (\boldsymbol{P r s})$ & $\ln (\boldsymbol{P B C})$ \\
\hline $\ln (\mathrm{Z})$ & 1 & & & & \\
$\ln (\boldsymbol{T} \boldsymbol{p})$ & -0.011 & 1 & & & \\
$\ln (\boldsymbol{T m})$ & 0.000 & -0.072 & 1 & & \\
$\ln (\boldsymbol{P r s})$ & -0.002 & 0.012 & 0.973 & 1 & \\
$\ln (\boldsymbol{P B C})$ & $\mathbf{0 . 0 6 9 *}$ & 0.003 & $\mathbf{- 0 . 9 5 1 ^ { * }}$ & $\mathbf{- 0 . 9 7 3 ^ { * }}$ & 1 \\
\hline
\end{tabular}

*Correlation is significant at the 0.01 level

F test and adjusted $\mathrm{R}^{2}$ statistics of the multiple linear regression models indicated that all three models were effective predictors of PBC. According to model 1, which was developed to estimate PBC values depending on vehicle traffic effects and meteorological factors for the alignment section of the $\mathrm{RN} 2$, adjusted $\mathrm{R}^{2}$ was found as 0.635. Moreover, in Model 2 developed to estimate PBC values depending on vehicle traffic effects, curve parameters and meteorological factors for the curve section of the $\mathrm{RN} 2$, adjusted $\mathrm{R}^{2}$ was found as 0.711 . Model 3, which was developed to estimate PBC values for all sections of the RN1 depending on meteorological factors, adjusted $\mathrm{R}^{2}$ was found as 0.952 (Tables 12 and 13).

Table 12. Statistical summary of regression model RN1 and RN2

\begin{tabular}{c|c|c|c|c|c|c}
\hline Road No & Road section & N & Adjusted R $^{2}$ & Std. error of the estimate & F & Sig. \\
\hline RN2 & Alignment & 1668 & 0.635 & 0.750 & 582.219 & 0.000 \\
RN2 & Curve & 1371 & 0.711 & 0.664 & 421.854 & 0.000 \\
RN1 & All road & 2540 & 0.952 & 0.866 & 12519.627 & 0.000 \\
\hline
\end{tabular}


Table 13. Summary of regression model coefficient RN1 and RN2

\begin{tabular}{|c|c|c|c|c|c|c|}
\hline \multirow{2}{*}{$\begin{array}{c}\text { Model } \\
\text { no }\end{array}$} & \multirow{2}{*}{$\begin{array}{c}\text { Road } \\
\text { no }\end{array}$} & \multirow{2}{*}{$\begin{array}{l}\text { Road } \\
\text { section }\end{array}$} & \multirow[t]{2}{*}{ Model } & \multicolumn{2}{|c|}{$\begin{array}{c}\text { Unstandardized } \\
\text { coefficients }\end{array}$} & \multirow[t]{2}{*}{ Regression model } \\
\hline & & & & B & Sig. & \\
\hline \multirow{6}{*}{ Model 1} & \multirow{15}{*}{ RN2 } & \multirow{6}{*}{ Alignment } & Constant & -1.214 & 0.000 & \multirow{6}{*}{$\begin{array}{c}Y=-1.214+18.684 \ln (Z)- \\
5.519 Z+0.002 T p+0.0002 T n+0.0003 P s\end{array}$} \\
\hline & & & $\ln (\mathrm{Z})$ & 18.684 & 0.000 & \\
\hline & & & $\mathrm{Z}$ & -5.519 & 0.000 & \\
\hline & & & $\mathrm{Tp}$ & 0.002 & 0.007 & \\
\hline & & & $\mathrm{Tn}$ & 0.0002 & 0.000 & \\
\hline & & & Ps & 0.0003 & 0.019 & \\
\hline \multirow{9}{*}{ Model 2} & & \multirow{9}{*}{ Curve } & Constant & -1.387 & 0.000 & \multirow{9}{*}{$\begin{array}{c}\mathrm{Y}=-1.387+18.336 \ln (\mathrm{Z})- \\
5.326 \mathrm{Z}+0.021 \mathrm{CuL}+0.008 \mathrm{CuR} \\
+0.002 \mathrm{~T}+0.0003 \mathrm{Tn}+0.427 \mathrm{Pi}-0.0004 \mathrm{Ps}\end{array}$} \\
\hline & & & $\ln (\mathrm{Z})$ & 18.336 & 0.000 & \\
\hline & & & $\mathrm{Z}$ & -5.326 & 0.000 & \\
\hline & & & $\mathrm{CuL}$ & -0.021 & 0.000 & \\
\hline & & & $\mathrm{CuR}$ & 0.008 & 0.000 & \\
\hline & & & $\mathrm{Tp}$ & 0.002 & 0.005 & \\
\hline & & & $\mathrm{Tn}$ & 0.0003 & 0.000 & \\
\hline & & & $\mathrm{Pi}$ & 0.427 & 0.000 & \\
\hline & & & Ps & -0.0004 & 0.002 & \\
\hline \multirow{5}{*}{ Model 3} & \multirow{5}{*}{ RN1 } & \multirow{5}{*}{ All Road } & Constant & 17.867 & 0.000 & \multirow{5}{*}{$Y=e^{17.867+1.00 \ln (\mathrm{Z})-2.849 \ln (\operatorname{Prs})-0.130 \ln (T m)+0.065\left(T_{p}\right)}$} \\
\hline & & & $\ln (\mathrm{Z})$ & 1.001 & 0.000 & \\
\hline & & & $\ln (\operatorname{Prs})$ & -2.849 & 0.000 & \\
\hline & & & $\ln (\mathrm{Tm})$ & -0.130 & 0.003 & \\
\hline & & & $\ln (\mathrm{Tp})$ & 0.065 & 0.016 & \\
\hline
\end{tabular}

As it is seen in Table 12, according to results of RN1's adjusted $\mathrm{R}^{2}$ it was possible to closely estimate $\mathrm{PBC}$ without traffic effects on forest road.

Also, in the study, developed regression models validated with test data (observation data). Scatter plot for model 1 had a linear correlation with $\mathrm{R}^{2}=0.57$ between the observed and predicted PBC $(N=432)$, scatter plot model 2 had a linear correlation with $\mathrm{R}^{2}=0.59$ between the observed and predicted PBC $(N=369)$ while scatter plot for model 3 had a linear correlation with $\mathrm{R}^{2}=0.96$ between the observed and predicted PBC $(N=640)$ (Figs. 8, 9, and 10).

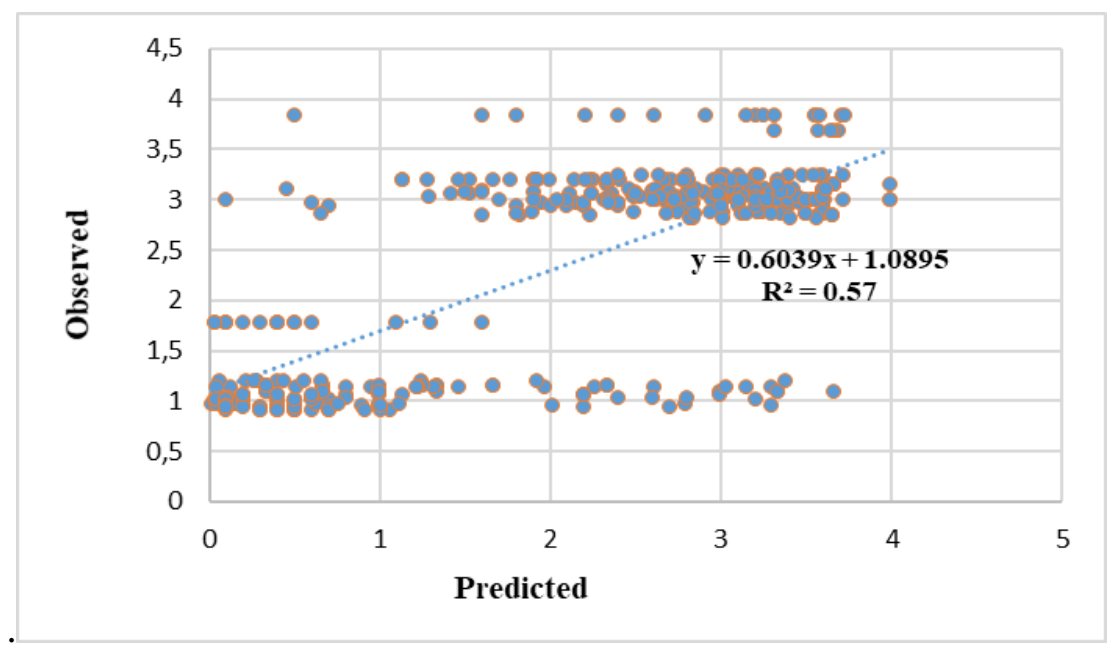

Figure 8. Validation of predicted and observed PBC values for model 1 


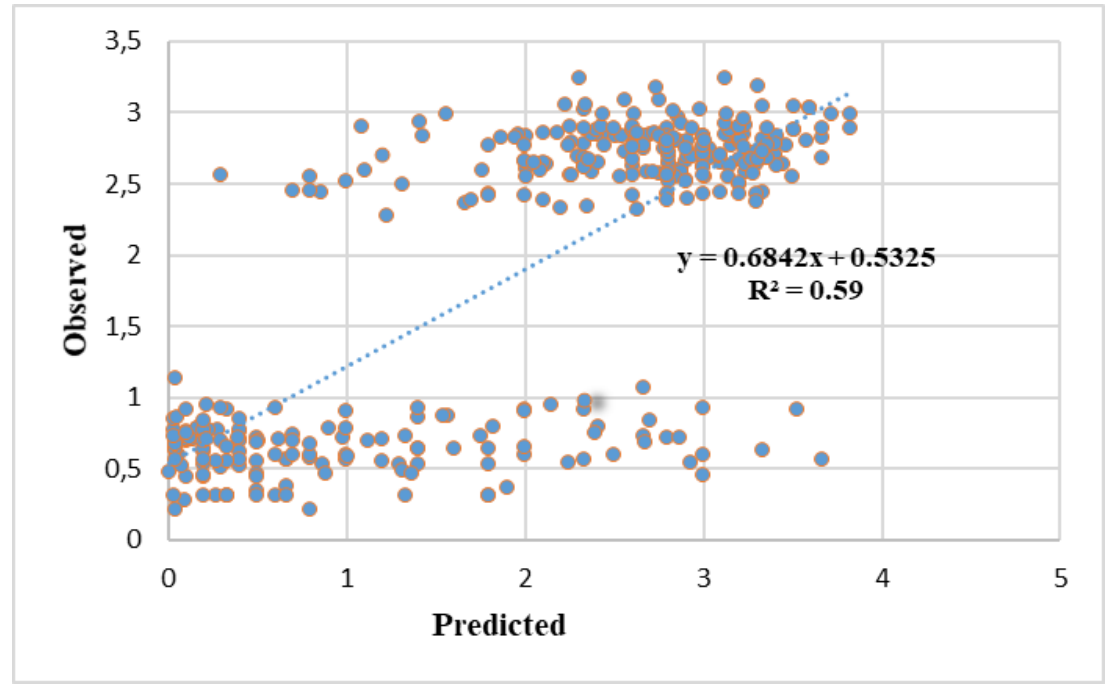

Figure 9. Validation of predicted and observed $P B C$ values for model 2

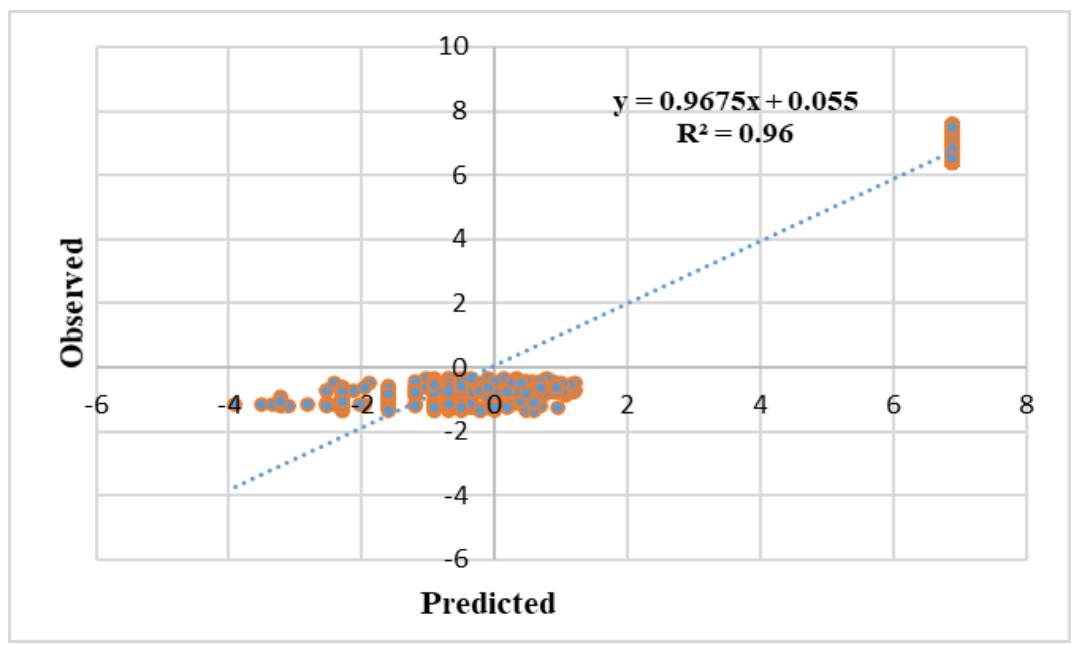

Figure 10. Validation of predicted and observed PBC values for model 3

Within the scope of the study, two different forest roads were investigated for monitoring the changes in $\mathrm{PBC}$ in one year. One of these roads was restricted to vehicle passages during the study. Hence, on this road (RN1); the effects of meteorological factors on PBC were investigated. Furthermore, on the other road (RN2), the changes in PBC were monitored depending on road sections, traffic effects and meteorological effects.

A comparison of the mean PBC between two roads, it was observed that PBC values on the RN2 were almost two or three times higher in the RN1. The most likely reason might be traffic load on the RN2. Similarly, Săceanu (2012) found a strong correlation between PBC and vehicle passages and tonnage. Our results showed that traffic load (vehicle passages and tonnage) was an important factor. In addition, during the measurement period on the RN2 which is open to traffic, there is a general decrease in the overall PBC values caused by the traffic load. In this regard, Salour (2015) stated that the combination of environmental factors and intensive vehicle traffic increased the 
deterioration of the road structure. The PBC values of the curve sections that we found were relatively lower than those of the alignment sections on the RN2. The possible reasons for that difference might include the changes (braking, accelerating) in the speed of the vehicles in the curve and alignment regions and lateral shifts of vehicles. Moreover, Das et al. (2016) reported that vehicle of placement in curve was different when compared to alignment, and the radius of curve also affected the lateral position of the vehicle.

PBC values were observed to be lower in spring than in other season. In order to explain the reason for this, Charlier et al. (2009) emphasized that the PBC decreases in spring because of the increase in the amount of moisture on subgrade. On the other hand, in connection with this, Yoshida et al. (2016) mentioned the need to have adequate drainage facilities to maintain the sustainability of the bearing capacity. Adlinge and Gupta (2013) also stated that moisture significantly reduced the strength of subgrade. Demir et al. (2012) and Erdem et al. (2018) stated that there is a parallel relationship to between monthly precipitation and sediment production. Monthly sediment production from unpaved forest road was significantly higher than that of paved forest road and undisturbed area. It clearly shows that a stabilizing cover on a forest road led to less sediment production and more soil protection (Demir et al., 2012; Erdem, 2018). The results of previous studies are similar to ours (Kaakkurivaara et al., 2015; Salour, 2015; Grajewski, 2016).

According to the correlation of the results, PBC values had a high negative correlation with Temperature (Tm) on RN1. Similar to these results, Pan et al. (2015) and Motiejūnas et al. (2010) reported that the increase in temperature on asphalt roads led to a decrease in the PBC. On the RN2, there was a strong relationship between PBC and road zone $(Z)$ values both in the curves and alignments. On the RN1, however, there was a weak relationship between PBC and zone (Z). This might be probably because there was no traffic load on the RN1 while there was traffic load on the RN2. According to the correlation results, $\mathrm{PBC}$ values had a high correlation with road zone. We have the impression that it was possibly due to the wheel track.

\section{Conclusions}

Road surface stability is an important factor on sustainability of forest operations in all seasons. In this context, the PBC value is an indication of the continuity of forest operations. Also, these values and models can be useful to managers for decision making stage in forestry activities.

So, traffic load, especially vehicle tonnage had a strong effect on PBC. On the other hand, temperature had a significant effect on the variation in PBC on the RN1. However, three multiple regression models were developed to estimate $\mathrm{PBC}$ values. According to the regression models, PBC values could be estimated at high accuracy. These models will also provide useful results to managers for decision-making in the future. Moreover, fixed measurement points constituted in study can be used to generate pavement compaction maps, PBC changes map etc. for future studies.

Acknowledgements. This paper is supported by the Scientific and Technological Research Council of Turkey (TUBITAK) with the grant number 2140214. Also, authors thank the editor and anonymous reviewers for their constructive comments, which helped us to improve the manuscript. 


\section{REFERENCES}

[1] Acar, H. H. (2016): Environmental sensitive road planning and transportation techniques in forest engineering. - Journal of the Faculty of Forestry Istanbul University 66(2): 710 726. DOI: $10.17099 /$ jffiu. 79204.

[2] Adlinge, S. S., Gupta, A. K. (2013): Pavement deterioration and its causes. International Journal of Innovative Research and Development 2: 437-450.

[3] Akay, A. O., Akgul, M., Demir, M. (2018): Determination of temporal changes on forest road pavement with terrestrial laser scanner. - Fresenius Environmental Bulletin 27(3): 1437-1448.

[4] Akgul, M., Hasdemir, M. (2018): Investigation on slope and canopy closure effects to minimize sediment movement in riparian buffer zone. - Forestist (formerly Journal of the Faculty of Forestry Istanbul University) 68(1): 70-77. DOI: 10.5152/forestist.2018.008.

[5] Akgul, M., Yurtseven, H., Akburak, S., Demir, M., Cigizoglu, K., Ozturk, T., Eksi, M. (2016): Terrestrial laser scanning based pavement degradation monitoring in the winter season. - 1st International Symposium of Forest Engineering and Technologies, 02-04 June, Bursa, Turkey.

[6] Akgul, M., Yurtseven, H., Akburak, S., Demir, M., Cigizoglu, H. K., Ozturk, T., Eksi., M Akay, A. O. (2017): Short term monitoring of forest road pavement degradation using terrestrial laser scanning. - Measurement 103: 283-293. DOI: 10.1016/j.measurement.2017.02.045.

[7] Bocz, P. (2009): The effect of stiffness and duration parameters to the service life of the pavement structure. - Periodica Polytechnica Civil Engineering 53(1): 35-41. DOI: 10. 33 11/pp.ci.2009-1.05.

[8] Charlier, R., Hornych, P., Sršen, M., Hermansson, Å., Bjarnason, G., Erlingsson, S., Pavšič, P. (2009): Water Influence on Bearing Capacity and Pavement Performance: Field Observations. - In: Dawson, A. (ed.) Water in Road Structures. Springer, Dordrecht.

[9] Das, V. R., Jayashree, M., Rahul, S. (2016): Lateral placement of vehicles on horizontal curves. - Transportation Research Procedia 17: 43-51. DOI: 10.1016/j.trpro.2016.11.059.

[10] Dawson, A. R. (2001): Engineering the forestry road pavement. - Annual Symposium on Forestry Engineering, Group of Inst. Agric. Engineers, Penrith, October, pp. 1-15.

[11] Demir, M. (2007): Impacts, management and functional planning criterion of forest road network system in Turkey. - Transportation Research Part A: Policy and Practice 41(1): 56-68. DOI: 10.1016/j.tra.2006.05.006.

[12] Demir, M., Hasdemir, M. (2005): Functional planning criterion of forest road network systems according to recent forestry development and suggestion in Turkey. - American Journal of Environmental Sciences 1(1): 22-28. DOI: 10.3844/ajessp.2005.22.28.

[13] Demir, M., Makineci, E., Kartaloglu, M. (2012): Temporal sediment production of paved and unpaved forest roads. - Fresenius Environmental Bulletin 21(5): 1180-1185.

[14] Domitrović, J., Rukavina, T. (2013): Application of GPR and FWD in assessing pavement bearing capacity. - Romanian Journal of Transport Infrastructure 2(2): 11-21. DOI: 10.1515/rjti-2015-0015.

[15] Erdem, R., Enez, K., Demir, M., Sariyildiz, T. (2018): Slope effect on the sediment production of forest roads in Kastamonu of Turkey. - Fresenius Environmental Bulletin 27(4): 2019-2025.

[16] GDM (2018): https://www.mgm.gov.tr/veridegerlendirme/il-ve-ilceleristatistik.aspx?m=ISTANBUL. - Accessed on 23 January 2019.

[17] Gokbulak, F., Uygur Erdogan, B., Yildirim, H. T., Ozcelik, M. S. (2018): Causes of land degradation and rehabilitation efforts of rangelands in Turkey. - Forestist (formerly Journal of the Faculty of Forestry Istanbul University) 68(2): 106-113. DOI: 10.26650/forestist.2018.396995. 
[18] Grajewski, S. M. (2016): Influence of pavement moisture content on the load-bearing capacity of forest road. - Infrastructure and Ecology of Rural Areas 4(2): pp. 1451-1462. DOI: http://dx.medra.org/10.14597/infraeco.2016.4.2.107.

[19] Haas, R. (2001): Reinventing the (pavement management) wheel. - Proceedings of the Fifth International Conference on Managing Pavements, August 11-14, 2001, Seattle, Washington.

[20] Kaakkurivaara, T., Vuorimies, N., Kolisoja, P., Uusitalo, J. (2015): Applicability of portable tools in assessing the bearing capacity of forest roads. - Silva Fennica 49(2): 126. DOI: $10.14214 /$ sf.1239.

[21] Kiss, K., Malinen, J., Tokola, T. (2016): Comparison of high and low density airborne lidar data for forest road quality assessment. - ISPRS Annals of Photogrammetry, Remote Sensing \& Spatial Information Sciences 3(8).

[22] Lugo, A. E., Gucinski, H. (2000): Function, effects, and management of forest roads. Forest Ecology and Management 133: 249-262. DOI: 10.1016/S0378-1127(99)00237-6.

[23] Motiejūnas, A., Paliukaitè, M., Vaitkus, A., Čygas, D. Laurinavičius, A. (2010): Research on the dependence of asphalt pavement stiffness upon the temperature of pavement layers. - The Baltic Journal of Road and Bridge Engineering 5(1): 50-54. DOI: 10.3846/bjrbe.2010.07.

[24] O'mahony, M. J., Ueberschaer, A., Owende, P. M. O., Ward, S. M. (2000): Bearing capacity of forest access roads built on peat soils. - Journal of Terramechanics 37(3): 127-138. DOI: 10.1016/S0022-4898(00)00003-3.

[25] Pan, F., Wang, L., Ji, J., Jing, W. (2015): Research review of flexible pavement temperature profile. - International Forum on Energy, Environment Science and Materials (IFEESM), Shenzhen, China, September, 25-26, pp. 724-727.

[26] Primusz, P., Péterfalvi, J., Markó, G., Tóth, C. (2015): Effect of pavement stiffness on the shape of deflection Bowl/A pályaszerkezet merevségének hatása a behajlási teknő alakjára. - Acta Silvatica et Lignaria Hungarica 11(1): pp.39-54. DOI: 10.1515/aslh2015-0003.

[27] Puppala, A. J. (2008): Estimating Stiffness of Subgrade and Unbound Materials for Pavement Design. - Transportation Research Board, Washington.

[28] Săceanu, C. (2012): Forest roads degradation in correlation with traffic characteristics. Proceedings of the Biennial International Symposium, Forest and Sustainable Development, Brașov, Romania, 19-20th October, pp. 133-138.

[29] Salour, F. (2015): Moisture influence on structural behavior of pavements: field and laboratory investigations. - PhD Thesis, KTH Royal Institute of Technology, Stockholm.

[30] Sheikh, V. B., Shalamzari, M. J., Farajollahi, A. (2017): Sediment-bound soil nutrient loss under simulated rainfall. - Journal of the Faculty of Forestry Istanbul University 67(1): 37-48. DOI: 10.17099/jffiu.95610.

[31] Szentpeteri, I. (2013): Temperature dependence of deflection bowl. - Proceedings of the Second Conference of Junior Researchers in Civil Engineering, Budapest, Hungary.

[32] Tighe, S., Haas, R., Ponniah, J. (2003): Life-cycle cost analysis of mitigating reflective cracking. - Transportation Research Record: Journal of the Transportation Research Board 1823: 73-79. DOI: 10.3141/1823-09.

[33] Trzcinski, G., Kaczmarzyk, S. (2006): Estimation of carrying capacity of slag and gravel forest road pavements. - Croatian Journal of Forest Engineering: Journal for Theory and Application of Forestry Engineering 27(1): 27-36.

[34] Vestin, J., Nordmark, D., Arm, M., Lind, B. B., Lagerkvist, A. (2018): Biofuel ash in road stabilization-Lessons learned from six years of field testing. - Transportation Geotechnics 14: 146-156. DOI: 10.1016/j.trgeo.2017.12.002.

[35] Wu, S., Sargand, S. M. (2007): Use of Dynamic Cone Penetrometer in Subgrade and Base Acceptance. - ORITE, Athens, Ohio. 
[36] Yoshida, M., Takahashi, H., Sakai, H. (2016): Analysis of alternative forest road retaining technologies on difficult slopes in Japan. - European Journal of Forest Engineering 2(2): 61-66.

[37] Yurtseven, H., Akgul, M., Akay, A. O., Akburak, S., Cigizoglu, H. K., Demir, M., Ozturk, T., Eksi, M. (2019): High accuracy monitoring system to estimate forest road surface degradation on horizontal curves. - Environmental Monitoring and Assessment 191(1): 32. DOI: 10.1007/s10661-018-7155-8. 